\title{
A new wave of urologists? Graduating urology residents' practices of and attitudes toward social media
}

Kunal Jain, BMSc ${ }^{1}$; Gagan Fervaha, $\mathrm{PhD}^{1}$, Michael B. Fuoco, MD, FRCSC ${ }^{2}$, and Michael J. Leveridge, MD, FRCSC ${ }^{2,3}$

${ }^{1}$ School of Medicine; ${ }^{2}$ Department of Urology; ${ }^{3}$ Department of Oncology' Queen’s University, Kingston, ON, Canada

Cite as: Can Urol Assoc J 2018 March 19; Epub ahead of print. http://dx.doi.org/10.5489/cuaj.5042

\section{Published online March 19, 2018}

\section{$* * *$}

\section{Abstract}

Introduction: Social media (SoMe) have revolutionized healthcare, but physicians remain hesitant to adopt SoMe in their practices. We sought to assess graduating urology residents' practices of and attitudes toward SoMe.

Methods: A close-ended questionnaire, employing five-point Likert scales, was distributed to all final-year residents $(\mathrm{n}=100)$ in Canadian urology training programs in 2012, 2014, and 2016 to assess SoMe usage and perceived usefulness.

Results: All (100\%) questionnaires were completed. Respondents frequently used online services for personal (100\%) and professional (96\%) purposes. Most (92\%) used SoMe. Many (73\%) frequently used SoMe for personal purposes, but few (12\%) frequently used SoMe for professional purposes. While a majority (59\%) opposed direct patient interaction online, most supported using SoMe to provide patients with static information (76\%) and collaborate with colleagues (65\%). Many (70-73\%) were optimistic that novel solutions to privacy issues in online communications will arise, making SoMe and email contact with patients conceivable. Few (2-8\%) were aware and had read guidelines and legislations regarding physician online practices; however, awareness of medical associations' and institutional SoMe policies significantly increased over time $(\mathrm{p}<0.05)$.

Conclusions: Despite their active online use, graduating urology residents rarely used SoMe in professional settings and were wary of using it in patient care. Nevertheless, they were optimistic toward its integration in urology and supported its use in physician-physician communication. Considering SoMe's increased influence on urology and graduating residents' limited awareness of guidelines and legislations, postgraduate medical educators should encourage residents to become more familiar with current online communication recommendations. 


\section{Introduction}

The rise of social media (SoMe), Web 2.0-based resources used to generate and share content online, has allowed passive internet users to become active contributors. Today, approximately $58 \%$ of Canadians and 2.31 billion people world-wide actively use SoMe, representing a 10\% global increase from last year. ${ }^{1}$

As it has with society, SoMe has pervaded into healthcare. ${ }^{2}$ SoMe offers healthcare professionals novel avenues to teach, learn, and care. ${ }^{3-7}$ Within urology, SoMe is used to conduct an international e-journal club, ${ }^{8}$ facilitate open-access discussions at conferences, ${ }^{9,10}$ disseminate information from prominent journals and societies, ${ }^{11}$ identify areas for improvement in educational resource distribution to patients, ${ }^{12-14}$ rapidly and accurately assess robotic surgical suturing performance, ${ }^{15}$ network professionally, ${ }^{16}$ and improve response rates to surveys. ${ }^{16}$ Due to the bourgeoning connection between SoMe and urology, a standardized nomenclature to discuss urologic topics online has been created. ${ }^{17}$

Despite its strong vocal support, ${ }^{18}$ SoMe's integration into urology has not been without its barriers. As compared to consultant urologists in other countries, ${ }^{19,20}$ consultant urologists in Canada have shown limited engagement in and perceived professional usefulness of SoMe. ${ }^{21}$ Physician uptake of SoMe has been slower than the general population's due to fears of legal ramifications, privacy issues, lack of compensation, and a perceived lack of efficiency. ${ }^{22}$ These concerns are valid, as some physicians and medical trainees have experienced disciplinary action for posting inappropriate content. ${ }^{23-25}$ Several medical organizations have developed professional SoMe use guidelines in response to these concerns. $^{26-32}$ Specific to urologists, BJU International (BJUI) and the European Association of Urology (EAU) have published guidelines for effective and responsible SoMe use. ${ }^{31,32}$

By nature of growing up in an era more invested in SoMe, the future generation of urologists may be more inclined to adopt SoMe. Recent studies have demonstrated that: young urology consultants rank SoMe as a more valuable information source than congresses and books, ${ }^{33}$ urology residents use SoMe more than consultants, ${ }^{19}$ and Canadian-educated urology residents' use SoMe for professional purposes and rate SoMe as useful for clinical purposes more often than their German-educated counterparts. ${ }^{34}$ However, professional SoMe use has not been studied further, less biased studies are needed, and graduating urology residents' engagement in and perceived professional usefulness of SoMe are unknown. This information is important, as graduating urology residents will become the newest cohort of urologists.

In our study, we sought to assess Canadian-educated, graduating urology residents' practices of and attitudes toward personal and professional SoMe use.

\section{Methods}

Our prospective study surveyed all final-year residents $(n=100)$ in Canadian urology training programs at the Queen's Urology Examination Skills Training (QUEST, a review course and mock board examination occurring two months prior to the board certification examination) program in $2012(n=31), 2014(n=37)$, and $2016(n=32)$ with a paper questionnaire. The 
questionnaire (Appendix A) modeled a previous survey ${ }^{21}$ that was designed to assess similar parameters for consultant urologists. Participation in the study was voluntary and kept confidential. Successful board examination completion data was obtained from Canadian Medical Association (CMA) Physician Data Centre. ${ }^{35}$ Queen's University Health Sciences and Affiliated Teaching Hospitals Research Ethics Board (HSREB) approval was granted.

The questionnaire used 88 close-ended questions with 5-point Likert scales to explore residents' engagement in SoMe and perceptions toward SoMe use (Appendix A). Questions were chosen to reflect the breadth of possible uses and attitudes, focusing on the following topics: use of online services, use of social networking sites, engagement in social networking sites, physicians' online interaction with patients, SoMe's role in health care, current online practice guidelines and legislations, physicians' responsibilities when using SoMe, and privacy or boundary issues in physicians' SoMe use.

We collated the results of the survey from paper using Microsoft Excel ${ }^{\circledR}$ (Microsoft, Redmond, Wash.). Two authors (KJ and GF) independently confirmed the transcription. For the purposes of reporting questions using the 5-point Likert scale, responses 1 and 2 were grouped together to describe infrequent use or an unsupportive attitude and responses 4 and 5 were grouped together to describe frequent use or a supportive attitude. Response 3 purported a null value, representing moderate use or a neutral attitude.

We used R 3.3.1 (R Foundation for Statistical Computing, Vienna, Aus.) and GraphPad Prism 7 statistical software package (GraphPad Software Inc., San Diego, Calif.) for data analysis. Descriptive statistics, Fisher's exact tests, and Pearson correlation coefficients were reported for participants' responses, changes in responses over the study period, and correlations, respectively. Our two-tailed $\alpha$-value was $5 \%$. Correlations were analyzed using the original, non-grouped data.

\section{Results}

Demographics

All (100\%) participants responded to the survey and successfully graduated.$^{35}$ Fifty-one (51\%) respondents desired a community-based clinical practice, forty-three (43\%) desired an academic-based clinical practice, and six (6\%) did not indicate a desired clinical practice.

\section{Current SoMe use}

Personal and professional use of online services

All (100\%) respondents frequently used online services in the past six months for personal purposes, and most (96\%) reported frequent professional use. A minority (1\%) reported never using online services for professional purposes.

The most frequently used online services for personal purposes were: email (100\%), text messaging (97\%), instant messaging (75\%), social networking sites (73\%), and online file storage and access (71\%). Regarding social networking sites, 73\% reported frequent use, 18\% 
reported infrequent use, and 9\% reported never using these sites. Over the study period, use of video-based services (48\% to 69\% frequent use) and wikis (55\% to 66\% frequent use) significantly increased ( $\mathrm{p}<0.05$; Figure 1 and supplementary eTable 1 ).

The most frequently used online services for professional purposes were: email (83\%), text messaging (83\%), online file storage and access (52\%), instant messaging (48\%), and wikis (15\%). Regarding social networking sites, $12 \%$ reported frequent use, $13 \%$ reported infrequent use, and 75\% reported never using these sites. Over the study period, use of instant messaging (29\% to $66 \%$ frequent use) and wikis (3\% to $34 \%$ frequent use) significantly increased, while awareness of social bookmarking sites (84\% to $72 \%$ aware) significantly decreased $(\mathrm{p}<0.05$; Figure 1 and supplementary eTable 1$)$.

\section{Use of social networking sites}

The most frequently used social networking sites were: Facebook ${ }^{\mathrm{TM}}(73 \%)$, YouTube ${ }^{\mathrm{TM}}(65 \%)$, Google ${ }^{\mathrm{TM}}(27 \%)$, and Twitter ${ }^{\mathrm{TM}}(15 \%)$. The least frequently used were: blogs (8\%), online physician communities (3\%), LinkedIn ${ }^{\mathrm{TM}}(2 \%)$, and patient advocacy groups' sites and patient communities (0\%). There were no significant differences in the use of these sites over the study period ( $\mathrm{p}>0.05$; Figure 2 and supplementary eTable 2).

Most respondents (92\%) used social networking sites, while a minority (7\%) reported no use at all. The majority (62\%) used these services for passive consumption (ie. viewing others' posted content). Other common uses included: communicating or coordinating with friends about upcoming plans (39\%), posting content or updates sporadically (36\%), and for sporadic updates (35\%). No (0\%) participants were authors of a blog or contributors to a blog other than their own. Participants level of engagement in these sites was not significantly different over the study period ( $\mathrm{p}>0.05)$.

Attitudes toward SoMe use

Physician-patient interaction online

Most respondents opposed using SoMe to "friend" patients on Facebook ${ }^{\mathrm{TM}}$ (96\%), follow a patient's Twitter ${ }^{\mathrm{TM}}$ account (90\%), “friend” patients on Facebook ${ }^{\mathrm{TM}}$ on a practice-dedicated page (78\%), encourage patients to follow a physician’s Twitter ${ }^{\mathrm{TM}}$ account (68\%), identifiably post on patient communities (60\%), email patients with results (53\%), anonymously post on patient communities to critique content or advise patients (50\%), and email patients with medical information (49\%). Most respondents (58\%) were indifferent to anonymous perusal of patient communities for understanding their opinions and needs. Support for identifiably posting on patient communities significantly decreased over the study period (16\% to 3\% support; $\mathrm{p}<0.05$; supplementary eTable 3). 


\section{SoMe's role in healthcare}

Most respondents supported SoMe's role in health care as a static information source about their practice or department for patients (76\%), a simple repository for reference material (eg. papers, slide decks, etc.) for personal use (71\%), a tool to keep in touch with colleagues' activities (65\%), a tool to inter-professionally discuss teaching or research activity (65\%), and a tool to foster establishment of new networking contacts for potential collaborations (50\%). However, most respondents opposed SoMe's role as a tool for direct patient interaction (59\%). Indifference toward SoMe's role as a static information source about practices for patients significantly decreased over the study period ( $13 \%$ to $3 \%$ indifference; $\mathrm{p}<0.05$ ); Table 1 ).

Guidelines and legislations regarding physician online practices and privacy issues Most respondents were unaware of the primary Canadian malpractice insurer's (Canadian Medical Protective Association (CMPA)) position on online communication with patients (65\%), SoMe policies by other medical representative or governing bodies (64\%), CMA's Physician Guidelines for Online Communication with Patients (63\%), provincial or state privacy and health information protection laws (58\%), and institutional SoMe policies (56\%). Awareness of institutional policies (20\% to $66 \%$ awareness) and those by other medical representative or governing bodies (16\% to 53\% awareness) significantly increased over the study period $(\mathrm{p}<0.05)$, supplementary eTable 4$)$.

\section{Responsibilities of physicians using SoMe for personal use}

Most respondents reported that physicians should be careful about what they post (91\%), complaining about work on SoMe should be avoided (85\%), evidence of "unprofessional" activity (ie. activities that are contrary to the accepted code of conduct) might (84\%) and should (54\%) put physicians at risk of disciplinary action, physicians should use rigorous privacy settings (84\%), discussing patients or cases should be avoided (83\%), and disciplinary and regulatory bodies should stay out of physicians' personal SoMe activities (56\%). Comparatively, most respondents (88\%) opposed "friending” patients on personal accounts. Support for whether evidence of "unprofessional" activity should put physicians at risk significantly decreased over the study period ( $61 \%$ to $44 \%$, $\mathrm{p}<0.05$; Table 2 ).

\section{Privacy and boundary issues in physician use of SoMe}

Most respondents felt that a comprehensive legal disclaimer should accompany online communications between physicians and patients (76\%); novel solutions to privacy issues will arise (73\%); SoMe and email contact with patients will be unavoidable, requiring regulatory colleges and CMPA to adapt rapidly (70\%); and interacting with patients on SoMe or through email should be avoided (68\%). Attitudes toward privacy and boundary issues in physician SoMe use did not significantly change over the study period ( $>>0.05$ ), Table 3 ). 


\section{Correlations among responses}

There were no significant correlations between respondents' desired clinical practice and SoMe use ( $p>0.05)$. Respondents who were interested in an academic practice were significantly less likely to support the role of SoMe services to coordinate an office or department's activities than those who were interested in a community practice $(\mathrm{r}=-0.22,95 \%$ Confidence Interval (CI) [-0.40,-0.01], $\mathrm{p}<0.05$ ). Respondents who did not use SoMe were significantly more likely to be aware of professional SoMe policies by other medical representative or governing bodies ( $\mathrm{r}=0.54,95 \% \mathrm{CI}[0.17,0.78])$, and of CMPA's position $(\mathrm{r}=0.52$ 95\%CI $[0.14,0.76])$ than those who $\operatorname{did}(\mathrm{p}<0.01)$.

\section{Discussion}

SoMe is ubiquitous and revolutionizing healthcare. Our study has helped elucidate graduating urology residents' practices of and attitudes toward personal and professional SoMe use.

\section{Current SoMe use}

We reported some of the highest usage rates of online services and social networking sites in published literature-slightly lower than those of all Canadian-educated urology residents ${ }^{34}$ but higher than those of consultant urologists ${ }^{19-21}$ and US-educated residents. ${ }^{19}$ While more graduating residents (73\%) used SoMe for personal purposes than consultants (26\%), the difference between the two groups for professional SoMe use was much more modest (12\% and $8 \%$, respectively). ${ }^{21}$ These comparisons suggest that graduating residents are more active SoMe users in their personal lives than consultants but may not see SoMe as professionally acceptable. This avoidance is likely a learned hesitation from consultants. ${ }^{22}$ However, the increased awareness and use of instant messaging, video-based services, and wikis among graduating residents suggest that these services are promising areas for integration of SoMe in urology.

Notably, those who did not use social networking sites were less likely to use specific SoMe services, offering internal validity to our results. Similarly, increased SoMe use among younger consultant urologists ${ }^{21,33}$ provided some external validation to our results and support for the hypothesis that younger generations are more acquainted with SoMe.

\section{Attitudes toward SoMe use}

\section{Online interactions}

Most graduating residents, as well as consultants, ${ }^{21}$ opposed online physician-patient interactions. Despite their frequent professional use of e-mailing (83\%), few residents and consultants ${ }^{21}$ endorsed interacting with patients involving test results and medical inquiries via e-mail. These findings suggest that messaging platforms in the professional setting are among colleagues rather than between physician and patient. However, graduating residents are keen on leveraging SoMe for patient care-residents showed more support for SoMe's role as a repository of information for physicians and patients than consultants. ${ }^{21}$ These are promising 
results, as it suggests that SoMe use at major urology conferences, ${ }^{10}$ as well as new online collaborative activities, such as the International Urology Journal Club, ${ }^{8}$ will continue to be well-received by future urologists. It also supports the notion that the minor increase in professional SoMe use, as compared to personal SoMe use, may be specific to SoMe's application to the current professional landscape.

\section{Physician responsibilities}

Graduating residents and consultants recognize their responsibilities when using SoMe. ${ }^{21}$ However, these residents appeared more dismayed than consultants by the restrictions placed on them-half (54\%) of graduating residents, as compared to two-thirds (68\%) of consultants, ${ }^{21}$ supported that "unprofessional" activities should put physicians at risk of disciplinary action, with residents providing less support for this statement over the study period. These findings suggest that graduating residents, while cognizant of the boundaries placed on their personal SoMe presence, perceive unfair judgment and intrusion of their personal SoMe activities. This belief may reflect generational differences between graduating residents and consultants. It is also possible that these residents are not fully aware of how activities in their personal life can negatively impact their professional career. ${ }^{22}$

\section{Future impact}

Promisingly, graduating residents recognize the future impact of SoMe on healthcare and appear to be more optimistic than consultants about the integration of SoMe in medical practice. ${ }^{21}$ One such novel application of SoMe to the professional environment are patient portals. Portals provide physicians with secure access to patient profiles, medical records, and lab reports, allowing physicians to provide follow-up messages to patients. In turn, patients can access educational documents, reminders for their medication management, and a schedule of their appointment bookings. It is possible that graduating residents may embrace this opportunity to enhance physician-patient online communications in their future practices. ${ }^{36}$

Awareness of guidelines and legislations

While graduating residents' and consultants ${ }^{21}$ limited awareness of guidelines and legislations are concerning, as posting unprofessional content online has resulted in disciplinary action, ${ }^{23-25}$ these finding highlight an opportunity to help urologists. Post-graduate medical educators can encourage residents to become more aware of SoMe policies, as there are roles for practicing safe and responsible SoMe use under several CanMEDS (Canada's framework for physician training) competencies. ${ }^{38}$ Consultants can also consider becoming more familiar with these policies, which would enable them to model safe SoMe use and support residents' learning environment.

Fortunately, graduating residents demonstrated increasing awareness of SoMe policies over time. This finding suggests that policies concerning professional SoMe use are valued and needed. Urologists with a keen interest in SoMe should consider contributing to the drafting of 
professional SoMe use policies in urology. Furthermore, while this finding was not associated with CMPA's policies, increased awareness of an electronic communications consent template ${ }^{37}$ that CMPA has created to help members address some of the medicolegal risks inherent in online communications may have increased professional SoMe use.

\section{Limitations}

There are several limitations to our study that merit consideration. First, we recognize that while the survey was created in an iterative process, it has not been validated; thus, survey bias is possible. Questions specific to residents, including modeling of preceptors' behavior and SoMe teaching received, were not added. Respondents may have also confused Google+TM with Google ${ }^{\mathrm{TM}}$, resulting in inflated values for questions concerning this service. Nevertheless, our survey was designed to be as encompassing as possible. Second, we recognize that we only surveyed three cohorts of Canadian-educated, graduating urology residents from 2012 to 2016; thus, the results may not be representative of all past, present, and future graduating urology residents and urology residents in Canada. Final-year residents are also unique-they may be searching for employment and this may decrease SoMe activity out of fear for being identified. Nonetheless, we expect that our results merit attention due to our high response rate $(100 \%)$ and appropriate timeline (five years) to demonstrate changes in SoMe's uptake. Finally, we appreciate the dynamic landscape of SoMe. Previously unimagined services have now become more relevant to the field of urology. Two major and well-described paradigms of SoMe experienced unanticipated emergence in urology: an international e-journal $\mathrm{club}^{8}$ and the "backchannel" use of SoMe at every major urology conference. ${ }^{9.10}$ Inclusion of these services may have resulted in higher professional SoMe use, as witnessed by Salem et al., ${ }^{34}$ and more favourable attitudes toward SoMe use, which may be artificially restricted by descriptions used at the time of survey development.

\section{Conclusion}

Our study showed that graduating residents from Canadian urology training programs are avid SoMe users in their personal lives but rarely use SoMe in professional settings and are wary of using it in patient care. Promisingly, this new generation of urologists are more optimistic than consultant urologists ${ }^{19}$ toward SoMe's integration in urology; they advocate for its utility in physician-physician communication and for providing patients with information. However, their limited awareness of current guidelines and legislations regarding online use is concerning. Post-graduate medical educators and consultants are poised to help urology residents become more informed about these recommendations.

As the connection between urology and SoMe continues to evolve, graduating urology residents' SoMe use should be supported and they should be encouraged to practice it safely. Helping them improve their understanding of SoMe's utility can lead to improved uptake in professional environments and more effective patient care. 


\section{References}

1. Kemp S; for We Are Social. Digital in 2016. We Are Social UK [Internet] 2017 [cited August 12, 2016]. https://www.slideshare.net/wearesocialsg/digital-in-2016 Accessed Nov 29, 2017.

2. Bosslet GT, Torke AM, Hickman SE, et al. The patient-doctor relationship and online social networks: results of a national survey. J Gen Intern Med 2011;26(10):1168-74.

3. Gao H, Barbier G, Goolsby R. Harnessing the crowdsourcing power of social media for disaster relief. IEEE Intell Syst 2011;26(3):10-4.

4. Lewis Jr M. Getting patients to 'like' your practice. Med Econ. 2010;87(23):22.

5. Attai DJ, Cowher MS, Al-Hamadani M, et al. Twitter social media is an effective tool for breast cancer patient education and support: patient-reported outcomes by survey. $J$ Med Internet Res 2015;17(7).

6. Dong C, Cheema M, Samarasekera D, et al. Using LinkedIn for continuing community of practice among hand surgeons worldwide. J Contin Educ Health Prof 2015;35(3):185-91.

7. Branford OA, Mallucci P. Publicize or perish! A guide to social media promotion of scientific articles: Featuring the Plastic and Reconstructive Surgery "Author Tool Kit”. Plast Reconst Surg 2015;136(4):579e-81e.

8. Thangasamy IA, Leveridge M, Davies BJ, et al. International Urology Journal Club via Twitter: 12-month experience. Eur Urol 2014;66(1):112-7.

9. Matta R, Doiron C, Leveridge MJ. The dramatic increase in social media in urology. $J$ Urol 2014;192(2):494-8.

10. Wilkinson SE, Basto MY, Perovic G, et al. The social media revolution is changing the conference experience: analytics and trends from eight international meetings. BJU Int 2015;115(5):839-46.

11. Murphy DG, Basto M. Social media@ BJUIjournal-what a start!. BJU Int 2013;111(7):1007-9.

12. Sajadi KP, Goldman HB. Social networks lack useful content for incontinence. Urology 2011;78(4):764-7.

13. Sood A, Sarangi S, Pandey A, et al. YouTube as a source of information on kidney stone disease. Urology 2011;77(3):558-62.

14. Steinberg PL, Wason S, Stern JM, et al. YouTube as source of prostate cancer information. Urology 2010;75(3):619-22.

15. Chen C, White L, Kowalewski T, et al. Crowd-sourced assessment of technical skills: a novel method to evaluate surgical performance. J Surgical Res 2014;187(1):65-71.

16. Borgmann H, DeWitt S, Tsaur I, et al. Novel survey disseminated through Twitter supports its utility for networking, disseminating research, advocacy, clinical practice and other professional goals. Can Urol Assoc J 2015;9(9-10):E713. 
17. Kutikov A, Woo HH, Catto JW. Urology tag ontology project: standardizing social media communication descriptors. Eur Urol 2016;69(2):183-5.

18. Trinh QD. Why I care about social media-and why you should too. BJU Int 2013;112(1):1-2.

19. Loeb S, Bayne CE, Frey C, et al. Use of social media in urology: data from the American Urological Association (AUA). BJU Int 2014;113(6):993-8.

20. Davies N, Murphy DG, Rij S, et al. Online and social media presence of Australian and New Zealand urologists. BJU Int 2015;116(6):984-9.

21. Fuoco M, Leveridge MJ. Early adopters or laggards? Attitudes toward and use of social media among urologists. BJU Int 2015;115(3):491-7.

22. George DR, Rovniak LS, Kraschnewski JL. Dangers and opportunities for social media in medicine. Clin Obstet Gynecol 2013;56(3).

23. Chretien KC, Greysen SR, Chretien JP, et al. Online posting of unprofessional content by medical students. JAMA 2009;302(12):1309-15.

24. Lagu T, Kaufman EJ, Asch DA, et al. Content of weblogs written by health professionals. J Gen Intern Med 2008;23(10):1642.

25. Koo K, Ficko Z, Gormley E. Unprofessional content on Facebook accounts of US urology residency graduates. BJU Int 2017;119(6):955-60.

26. AMA Policy. Professionalism in the use of social media. American Medical Association 2011.

27. Canadian Medical Association. Social media and Canadian physicians-issues and rules of engagement. Canadian Medical Association [Internet] 2011 [cited August 12, 2016]. http://www.cma.ca/socialmedia. Accessed November 29, 2017.

28. Canadian Medical Protective Association. Good practices guide. Canadian Medical Protective Association [Internet] [cited August 12, 2016]. https://www.cmpaacpm.ca/serve/docs/ela/goodpracticesguide/pages/communication/Privacy_and_Confid entiality/ecommunication-e.html. Accessed November 29, 2017.

29. College of Physicians and Surgeons of Alberta. Social media: what physicians need to know. College of Physicians and Surgeons of Alberta [Internet] 2015 [cited August 12, 2016]. http://cpsa.ca/wp-content/uploads/2015/08/Social-Media-Advice-Document.pdf. Accessed November 29, 2017.

30. Dizon DS, Graham D, Thompson MA, et al. Practical guidance: the use of social media in oncology practice. Oncol Pract 2012;8(5):e114-24.

31. Murphy DG, Loeb S, Basto MY, et al. Engaging responsibly with social media: the BJUI guidelines. BJU Int 2014;114(1):9-11.

32. Rouprêt M, Morgan TM, Bostrom PJ, et al. European Association of Urology (@ Uroweb) recommendations on the appropriate use of social media. Eur Urol 2014;66(4):628-32. 
33. Rivas JG, Socarras MR, Patruno G, et al. Perceived Role of Social Media in Urologic Knowledge Acquisition Among Young Urologists: A European Survey. Eur Urol Focus 2017.

34. Salem J, Borgmann H, Baunacke M, et al. Widespread use of internet, applications, and social media in the professional life of urology residents. Can Urol Assoc $J$ 2017;11(9):355-66.

35. Canadian Medical Association. CMA Physician Data Centre. Canadian Medical Association [Internet] [cited August 12, 2016]. https://www.cma.ca/En/Pages/cmaphysician-data-centre.aspx. Accessed November 29, 2017.

36. Coach: Canada's Health Informatics Association. Privacy \& security for patient portals: 2012 guidelines for the protection of health information, special edition. Canada's Health Informatics Association [Internet] 2012. http://www.ehealthontario.on.ca/images/uploads/pages/documents/PrivacySecurity-for-Patient-Portals.pdf. Accessed November 29, 2017.

37. Canadian Medical Protective Association. Consent to use electronic communication. Canadian Medical Protective Association [Internet] 2016 [cited August 12, 2016]. https://www.cmpa-acpm.ca/static-assets/pdf/advice-and-publications/riskmanagement-toolbox/com_16_consent_to_use_electronic_communication_form-e.pdf. Accessed August 12, 2016.

38. Royal College of Physicians and Surgeons of Canada. CanMEDS Physician Competency Framework. Royal College of Physicians and Surgeons of Canada [Internet] 2017 [cited August 12, 2016]. http://www.royalcollege.ca/rcsite/canmeds-e. August 12, 2016. 


\section{Figures and Tables}

Fig. 1. Graduating urology residents' use (\%) of the top 5 most notable online services in the personal and professional settings.

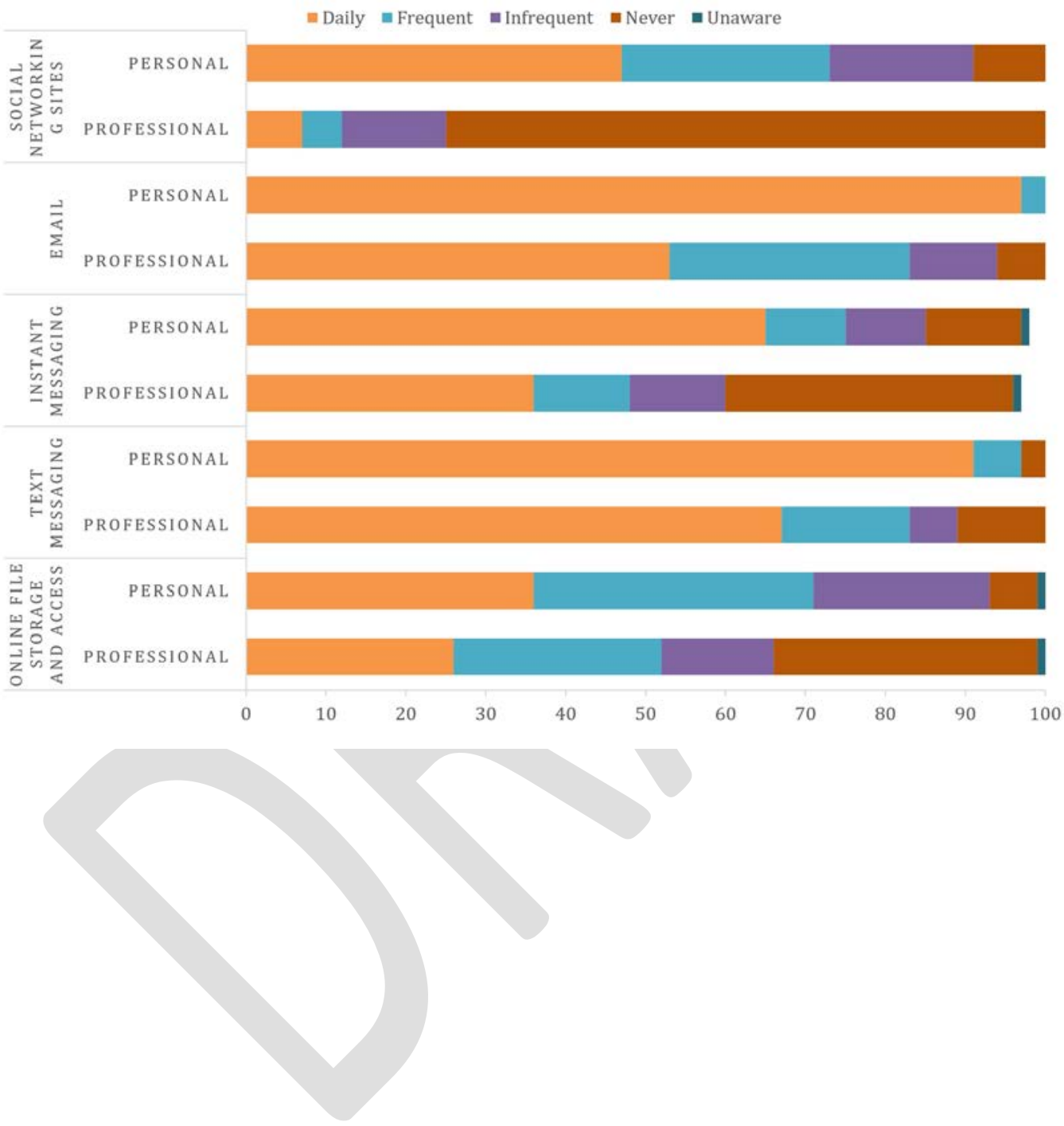


Fig. 2. Graduating urology residents' use (\%) of the top 5 most notable social networking sites.

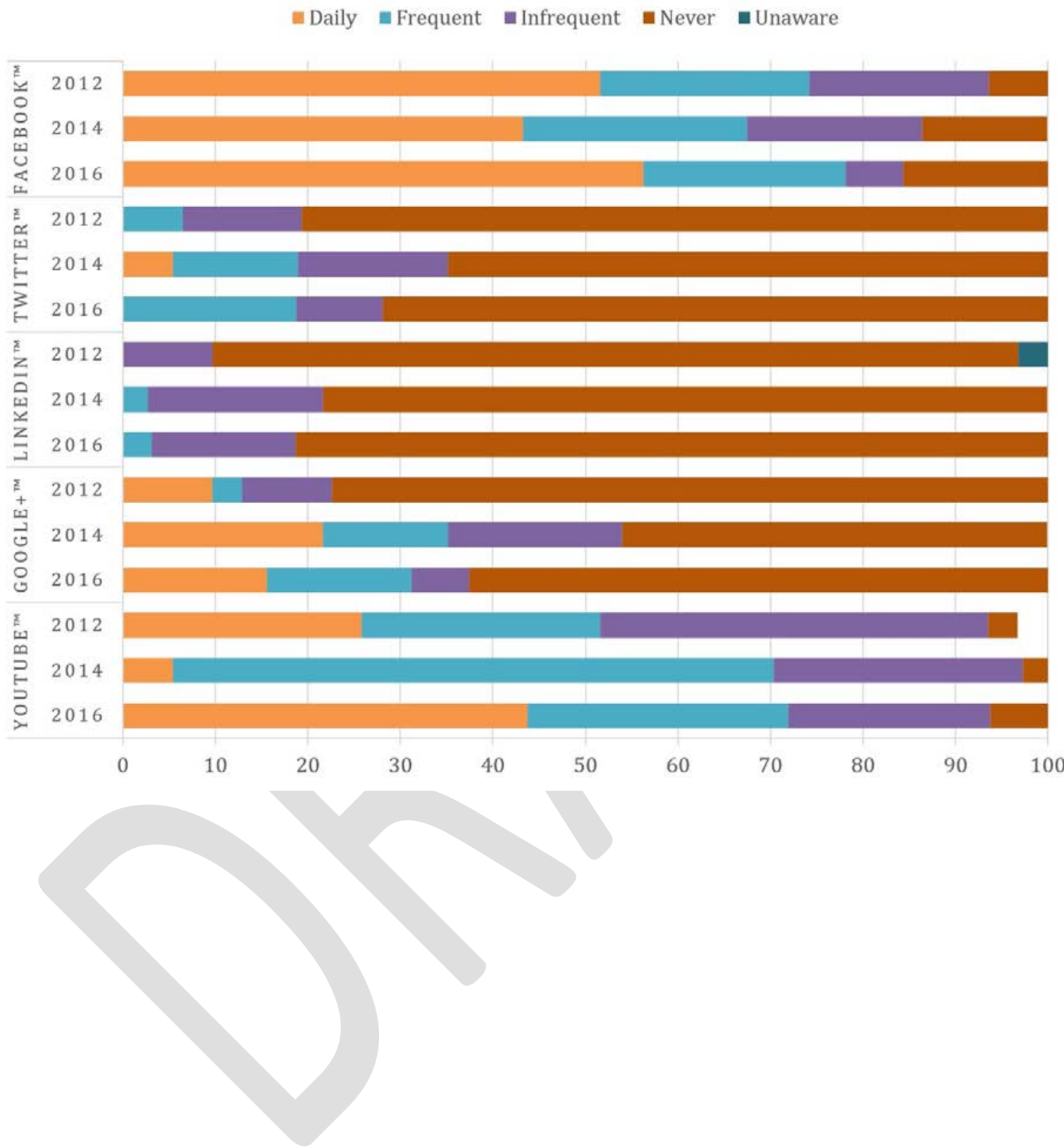


Table 1. Responses to "What are your thoughts regarding the role of social media services in healthcare?"

\begin{tabular}{|c|c|c|c|c|c|c|}
\hline & & & Count (\%) & & & \\
\hline Response & Attitude & $\begin{array}{c}2012 \\
(n=31)\end{array}$ & $\begin{array}{c}2014 \\
(n=37)\end{array}$ & $\begin{array}{c}2016 \\
(n=32)\end{array}$ & $\begin{array}{c}\text { Avg. } \\
(\%) \\
(n=100 \\
)\end{array}$ & $\mathbf{p}$ \\
\hline Should be a simple & Support & $21(67.7)$ & $25(67.6)$ & $25(78.1)$ & 71 & 0.75 \\
\hline repository for reference & Indifferent & $7(22.6)$ & $8(21.6)$ & $5(15.6)$ & 20 & \\
\hline material for personal use & Against & $1(3.2)$ & $4(10.8)$ & $2(6.2)$ & 7 & \\
\hline & No answer & $2(6.5)$ & $0(0.0)$ & $0(0.0)$ & 2 & \\
\hline Should be a static & Support & $25(80.6)$ & $23(65.7)$ & $28(87.5)$ & 76 & 0.04 \\
\hline information source & Indifferent & $4(12.9)$ & $10(28.6)$ & $1(3.1)$ & 15 & \\
\hline about your practice or & Against & $1(3.2)$ & $2(5.7)$ & $3(9.4)$ & 6 & \\
\hline department for patients & No answer & $1(3.2)$ & $0(0.0)$ & $0(0.0)$ & 1 & \\
\hline Keeping in touch with & Support & $17(54.8)$ & $25(67.6)$ & $23(71.9)$ & 65 & 0.47 \\
\hline colleagues' activities & Indifferent & $13(41.9)$ & $11(29.7)$ & $8(25.0)$ & 32 & \\
\hline & Against & $0(0.0)$ & $1(2.7)$ & $1(3.1)$ & 2 & \\
\hline & No answer & $1(3.2)$ & $0(0.0)$ & $0(0.0)$ & 1 & \\
\hline Interprofessional & Support & $19(61.3)$ & $23(62.2)$ & $23(71.9)$ & 65 & 0.30 \\
\hline discussion of teaching & Indifferent & $11(35.5)$ & $11(29.7)$ & $6(18.8)$ & 28 & \\
\hline research activity & Against & $0(0.0)$ & $3(8.1)$ & $3(9.4)$ & 6 & \\
\hline & No answer & $1(3.2)$ & $0(0.0)$ & $0(0.0)$ & 1 & \\
\hline Interprofessional & Support & $12(38.7)$ & 17 (45.9) & $8(25.0)$ & 37 & 0.38 \\
\hline discussion of patient & Indifferent & $9(29.0)$ & 7 (18.9) & $10(31.3)$ & 26 & \\
\hline cases & Against & $9(29.0)$ & $13(35.1)$ & $14(43.8)$ & 36 & \\
\hline & No answer & $1(3.2)$ & $0(0.0)$ & $0(0.0)$ & 1 & \\
\hline Marketing and & Support & $6(19.4)$ & $10(27.0)$ & 7 (21.9) & 23 & 0.92 \\
\hline promotion of oneself or & Indifferent & $15(48.4)$ & $16(43.2)$ & $17(53.1)$ & 48 & \\
\hline their practice & Against & $9(29.0)$ & $11(29.7)$ & $8(25.0)$ & 28 & \\
\hline & No answer & $1(3.2)$ & $0(0.0)$ & $0(0.0)$ & 1 & \\
\hline A tool for direct patient & Support & $6(19.4)$ & $4(10.8)$ & $4(12.5)$ & 14 & 0.29 \\
\hline interaction & Indifferent & $11(35.5)$ & $9(24.3)$ & $6(18.8)$ & 26 & \\
\hline & Against & 13 (41.9) & $24(64.9)$ & $22(68.8)$ & 59 & \\
\hline & No answer & $1(3.2)$ & $0(0.0)$ & $0(0.0)$ & 1 & \\
\hline Coordination of an & Support & $12(38.7)$ & $19(51.4)$ & $17(53.1)$ & 48 & 0.54 \\
\hline office or department's & Indifferent & $16(51.6)$ & $12(32.4)$ & $12(37.5)$ & 40 & \\
\hline activities & Against & $2(6.5)$ & $5(13.5)$ & $3(9.4)$ & 10 & \\
\hline
\end{tabular}




\begin{tabular}{|l|c|c|c|c|c|c|}
\hline & No answer & $1(3.2)$ & $1(2.7)$ & $0(0.0)$ & 2 & \\
\hline Fostering establishment & Support & $14(45.2)$ & $20(54.1)$ & $16(50)$ & 50 & 0.77 \\
of new networking & Indifferent & $13(41.9)$ & $11(29.7)$ & $13(40.6)$ & 37 & \\
contacts for potential & Against & $3(9.7)$ & $6(16.2)$ & $3(9.4)$ & 12 & \\
collaborations & No answer & $1(3.2)$ & $0(0.0)$ & $0(0.0)$ & 1 & \\
\hline
\end{tabular}

Note: Support, indifferent, and negative attitudes were compared using Fisher's exact test to calculate $\mathrm{p}$ values. $\mathrm{P}$ values were reported as the probability of the observed array of cell frequencies plus the sum of the probabilities of all other cell frequency arrays that were equal to or smaller than the probability of the observed array. $\mathrm{P}$ values $<0.05$ were considered significant. Avg.: average for total study period.

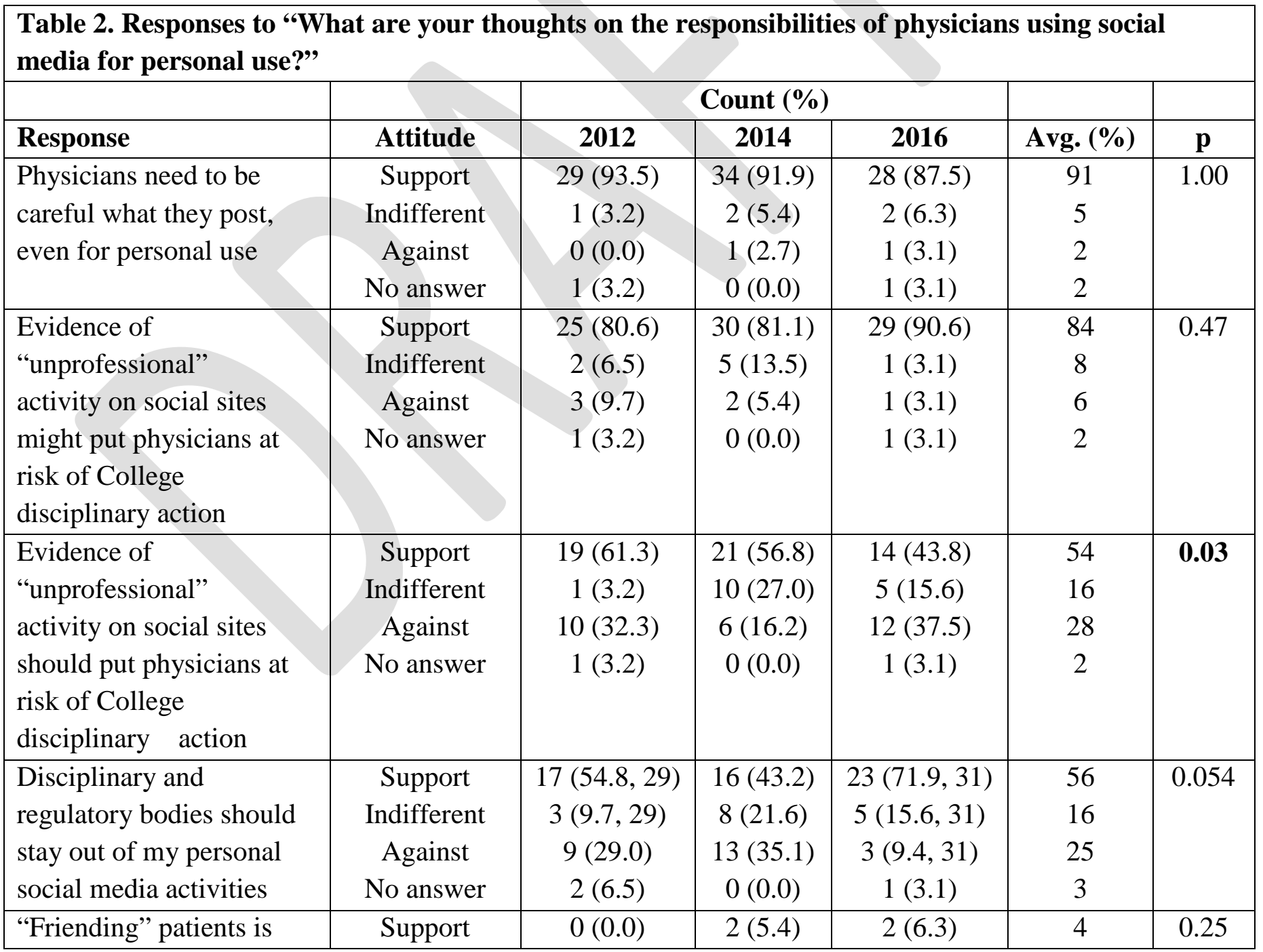




\begin{tabular}{|c|c|c|c|c|c|c|}
\hline $\begin{array}{l}\text { acceptable on my } \\
\text { personal accounts }\end{array}$ & $\begin{array}{c}\text { Indifferent } \\
\text { Against } \\
\text { No answer }\end{array}$ & $\begin{array}{c}1(3.2) \\
29(93.5) \\
1(3.2)\end{array}$ & $\begin{array}{c}1(2.7) \\
34(91.9) \\
0(0.0)\end{array}$ & $\begin{array}{c}4(12.5) \\
25(78.1) \\
1(3.1)\end{array}$ & $\begin{array}{c}6 \\
88 \\
2\end{array}$ & \\
\hline $\begin{array}{l}\text { Physicians, more than the } \\
\text { lay public, should use } \\
\text { rigorous privacy settings } \\
\text { on their social media } \\
\text { accounts }\end{array}$ & $\begin{array}{c}\text { Support } \\
\text { Indifferent } \\
\text { Against } \\
\text { No answer }\end{array}$ & $\begin{array}{c}27(87.1) \\
3(9.7) \\
0(0.0) \\
1(3.2)\end{array}$ & $\begin{array}{c}28(75.7) \\
6(16.2) \\
3(8.1) \\
0(0.0)\end{array}$ & $\begin{array}{c}29(90.6) \\
2(6.3) \\
0(0.0) \\
1(3.1)\end{array}$ & $\begin{array}{c}84 \\
11 \\
3 \\
2\end{array}$ & 0.19 \\
\hline $\begin{array}{l}\text { Discussing patients or } \\
\text { cases, even without using } \\
\text { names, should be avoided } \\
\text { on personal social media } \\
\text { accounts }\end{array}$ & $\begin{array}{c}\text { Support } \\
\text { Indifferent } \\
\text { Against } \\
\text { No answer }\end{array}$ & $\begin{array}{c}26(83.9) \\
3(9.7) \\
1(3.2) \\
1(3.2)\end{array}$ & $\begin{array}{c}30(81.1) \\
2(5.4) \\
5(13.5) \\
0(0.0)\end{array}$ & $\begin{array}{c}27(84.4) \\
2(6.3) \\
2(6.3) \\
1(3.1)\end{array}$ & $\begin{array}{c}83 \\
7 \\
8 \\
2\end{array}$ & 0.63 \\
\hline $\begin{array}{l}\text { Complaining about work } \\
\text { on social networking sites } \\
\text { should be avoided }\end{array}$ & $\begin{array}{c}\text { Support } \\
\text { Indifferent } \\
\text { Against } \\
\text { No answer }\end{array}$ & $\begin{array}{c}24(77.4)) \\
4(12.9) \\
2(6.5) \\
1(3.2)\end{array}$ & $\begin{array}{c}32(86.5) \\
2(5.4) \\
3(8.1) \\
0(0.0)\end{array}$ & $\begin{array}{c}29(90.6) \\
2(6.3) \\
0(0.0) \\
1(3.1)\end{array}$ & $\begin{array}{c}85 \\
8 \\
5 \\
2\end{array}$ & 0.39 \\
\hline
\end{tabular}

Note: Support and against attitudes were compared using Fisher's exact test to calculate $\mathrm{p}$ values. $\mathrm{P}$ values were reported as the probability of the observed array of cell frequencies plus the sum of the probabilities of all other cell frequency arrays that were equal to or smaller than the probability of the observed array. P values $<0.05$ were considered significant. Avg.: average.

\begin{tabular}{|c|c|c|c|c|c|c|}
\hline & & & Sount (\%) & & & \\
\hline Response & Attitude & 2012 & 2014 & 2016 & $\begin{array}{l}\text { Avg. } \\
(\%)\end{array}$ & $\mathbf{p}$ \\
\hline $\begin{array}{l}\text { Interacting with a patient } \\
\text { on a social site or through } \\
\text { email should be avoided }\end{array}$ & $\begin{array}{l}\text { Support } \\
\text { Indifferent } \\
\text { Against } \\
\text { No answer }\end{array}$ & $\begin{array}{c}21(67.7) \\
3(9.7) \\
5(16.1) \\
2(6.5)\end{array}$ & $\begin{array}{c}28(75.7) \\
4(10.8) \\
5(13.5) \\
0(0.0)\end{array}$ & $\begin{array}{c}19(59.4) \\
6(18.8) \\
6(18.8) \\
1(3.1)\end{array}$ & $\begin{array}{c}68 \\
13 \\
16 \\
3\end{array}$ & 0.73 \\
\hline $\begin{array}{l}\text { Integration of social media } \\
\text { in medical practice will be } \\
\text { impossible, as boundary, } \\
\text { privacy, and litigation } \\
\text { issues are too ingrained in }\end{array}$ & $\begin{array}{l}\text { Support } \\
\text { Indifferent } \\
\text { Against } \\
\text { No answer }\end{array}$ & $\begin{array}{c}12(38.7) \\
7(22.6) \\
10(32.3) \\
2(6.5)\end{array}$ & $\begin{array}{c}16(43.2) \\
7(18.9) \\
14(37.8) \\
0(0.0)\end{array}$ & $\begin{array}{c}13(40.6) \\
9(28.1) \\
9(28.1) \\
1(3.1)\end{array}$ & $\begin{array}{c}41 \\
23 \\
33 \\
3\end{array}$ & 0.89 \\
\hline
\end{tabular}




\begin{tabular}{|c|c|c|c|c|c|c|}
\hline \multirow[b]{2}{*}{$\begin{array}{l}\text { medical practice } \\
\text { A zero-contact policy } \\
\text { between physicians and } \\
\text { patients makes sense until } \\
\text { the provincial Colleges of } \\
\text { Physicians and Surgeons } \\
\text { and the CMPA can draft } \\
\text { appropriate guidelines }\end{array}$} & & & & & & \\
\hline & $\begin{array}{c}\text { Support } \\
\text { Indifferent } \\
\text { Against } \\
\text { No answer }\end{array}$ & $\begin{array}{c}15(48.4) \\
9(29.0) \\
5(16.1) \\
2(6.5)\end{array}$ & $\begin{array}{c}14(37.8) \\
15(40.5) \\
8(21.6) \\
0(0.0)\end{array}$ & $\begin{array}{c}12(37.5) \\
8(25.0) \\
11(34.4) \\
1(3.1)\end{array}$ & $\begin{array}{c}41 \\
32 \\
24 \\
3\end{array}$ & 0.41 \\
\hline $\begin{array}{l}\text { The provincial Colleges of } \\
\text { Physicians and Surgeons } \\
\text { and the CMPA will need } \\
\text { to adapt rapidly, as social } \\
\text { media and email contact } \\
\text { with patients is } \\
\text { unavoidable in the future }\end{array}$ & $\begin{array}{c}\text { Support } \\
\text { Indifferent } \\
\text { Against } \\
\text { No answer }\end{array}$ & $\begin{array}{c}21(67.7) \\
6(19.4) \\
2(6.5) \\
2(6.5)\end{array}$ & $\begin{array}{c}27(73.0) \\
9(24.3) \\
1(2.7) \\
0(0.0)\end{array}$ & $\begin{array}{c}22(68.8) \\
8(25.0) \\
1(3.1) \\
1(3.1)\end{array}$ & $\begin{array}{c}70 \\
23 \\
4 \\
3\end{array}$ & 0.93 \\
\hline $\begin{array}{l}\text { There will be novel } \\
\text { solutions to privacy issues } \\
\text { in online communications }\end{array}$ & $\begin{array}{c}\text { Support } \\
\text { Indifferent } \\
\text { Against } \\
\text { No answer }\end{array}$ & $\begin{array}{c}20(64.5) \\
6(19.4) \\
2(6.5) \\
3(9.7)\end{array}$ & $\begin{array}{c}30(81.1) \\
6(16.2) \\
1(2.7) \\
0(0.0)\end{array}$ & $\begin{array}{c}23(71.9) \\
5(15.6) \\
3(9.4) \\
1(3.1)\end{array}$ & $\begin{array}{c}73 \\
17 \\
6 \\
4\end{array}$ & 0.74 \\
\hline $\begin{array}{l}\text { A comprehensive legal } \\
\text { disclaimer should } \\
\text { accompany any online } \\
\text { communication between } \\
\text { physicians and patients }\end{array}$ & $\begin{array}{c}\text { Support } \\
\text { Indifferent } \\
\text { Against } \\
\text { No answer }\end{array}$ & $\begin{array}{c}21(67.7) \\
5(16.1) \\
3(9.7) \\
2(6.5)\end{array}$ & $\begin{array}{c}30(81.1) \\
6(16.2) \\
0(0.0) \\
1(2.7)\end{array}$ & $\begin{array}{c}25(78.1) \\
5(15.6) \\
1(3.1) \\
1(3.1)\end{array}$ & $\begin{array}{c}76 \\
16 \\
4 \\
4\end{array}$ & 0.42 \\
\hline $\begin{array}{l}\text { I would be protected from } \\
\text { legal or College action by } \\
\text { the use of a } \\
\text { comprehensive legal } \\
\text { disclaimer appended to } \\
\text { my emails to patients }\end{array}$ & $\begin{array}{c}\text { Support } \\
\text { Indifferent } \\
\text { Against } \\
\text { No answer }\end{array}$ & $\begin{array}{c}6(19.4) \\
8(25.8) \\
15(48.4) \\
2(6.5)\end{array}$ & $\begin{array}{c}11(29.7) \\
11(29.7) \\
15(40.5) \\
0(0.0)\end{array}$ & $\begin{array}{c}9(28.1) \\
9(28.1) \\
13(40.6) \\
1(3.1)\end{array}$ & $\begin{array}{c}26 \\
28 \\
43 \\
3\end{array}$ & 0.90 \\
\hline
\end{tabular}

Note: Support and against attitudes were compared using Fisher's exact test to calculate $\mathrm{p}$ values. $\mathrm{P}$ values were reported as the probability of the observed array of cell frequencies plus the sum of the probabilities of all other cell frequency arrays that were equal to or smaller than the probability of the observed array. P values $<0.05$ were considered significant. Avg.: average. 


\section{Supplemetary tables}

Supplementary Table 1. Percentages of frequent and infrequent users of online services for personal and professional purposes in the past 6 months.

\begin{tabular}{|c|c|c|c|c|c|c|c|c|c|c|c|}
\hline \multirow[b]{2}{*}{$\begin{array}{l}\text { Type of } \\
\text { social media }\end{array}$} & \multirow[b]{2}{*}{ Rate } & \multicolumn{5}{|c|}{ Personal use (\%) } & \multicolumn{5}{|c|}{ Professional use (\%) } \\
\hline & & $\begin{array}{c}2012 \\
(n=31)\end{array}$ & $\begin{array}{c}2014 \\
(n=37)\end{array}$ & $\begin{array}{c}2016 \\
(n=32)\end{array}$ & $\begin{array}{c}\text { Avg. } \\
(\%) \\
(n=100)\end{array}$ & $\mathbf{p}$ & $\begin{array}{c}2012 \\
(n=31)\end{array}$ & $\begin{array}{c}2014 \\
(n=37)\end{array}$ & $\begin{array}{c}2016 \\
(n=32)\end{array}$ & $\begin{array}{c}\text { Avg. } \\
(\%) \\
(n=100)\end{array}$ & $\mathbf{p}$ \\
\hline $\begin{array}{l}\text { Social } \\
\text { networking } \\
\text { sites }\end{array}$ & $\begin{array}{l}\text { Frequent } \\
\text { Infrequent } \\
\text { Unaware } \\
\text { No answer }\end{array}$ & $\begin{array}{c}24(77.4) \\
7(22.6) \\
0(0.0) \\
0(0.0)\end{array}$ & $\begin{array}{c}25(67.6) \\
12(32.4) \\
0(0.0) \\
0(0.0)\end{array}$ & $\begin{array}{c}24(75.0) \\
8(25.0) \\
0(0.0) \\
0(0.0) \\
\end{array}$ & $\begin{array}{c}73 \\
27 \\
0 \\
0\end{array}$ & 0.66 & $\begin{array}{c}2(6.5) \\
29(93.5) \\
0(0.0) \\
0(0.0)\end{array}$ & $\begin{array}{c}7(18.9) \\
30(81.1) \\
0(0.0) \\
0(0.0)\end{array}$ & $\begin{array}{c}3(9.4) \\
29(90.6) \\
0(0.0) \\
0(0.0)\end{array}$ & $\begin{array}{c}12 \\
88 \\
0 \\
0\end{array}$ & 0.29 \\
\hline Email & $\begin{array}{l}\text { Frequent } \\
\text { Infrequent } \\
\text { Unaware } \\
\text { No answer }\end{array}$ & $\begin{array}{c}31(100) \\
0(0.0) \\
0(0.0) \\
0(0.0) \\
\end{array}$ & $\begin{array}{c}37(100) \\
0(0.0) \\
0(0.0) \\
0(0.0) \\
\end{array}$ & $\begin{array}{c}32(100) \\
0(0.0) \\
0(0.0) \\
0(0.0) \\
\end{array}$ & $\begin{array}{c}100 \\
0 \\
0 \\
0 \\
\end{array}$ & 1.00 & $\begin{array}{c}24(77.4) \\
7(22.6) \\
0(0.0) \\
0(0.0) \\
\end{array}$ & $\begin{array}{c}32(86.5) \\
5(13.5) \\
0(0.0) \\
0(0.0) \\
\end{array}$ & $\begin{array}{c}27(84.4) \\
5(15.6) \\
0(0.0) \\
0(0.0) \\
\end{array}$ & $\begin{array}{c}83 \\
17 \\
0 \\
0 \\
\end{array}$ & 0.57 \\
\hline $\begin{array}{l}\text { Instant } \\
\text { messaging }\end{array}$ & $\begin{array}{l}\text { Frequent } \\
\text { Infrequent } \\
\text { Unaware } \\
\text { No answer }\end{array}$ & $\begin{array}{c}22(71.0) \\
8(25.8) \\
1(3.2) \\
0(0.0)\end{array}$ & $\begin{array}{c}28(75.7) \\
7(18.9) \\
0(0.0) \\
2(5.4)\end{array}$ & $\begin{array}{c}25(78.1) \\
7(21.9) \\
0(0.0) \\
0(0.0)\end{array}$ & $\begin{array}{c}75 \\
22 \\
1 \\
2\end{array}$ & 0.60 & $\begin{array}{c}9(29.0) \\
21(67.7) \\
1(3.2) \\
0(0.0)\end{array}$ & $\begin{array}{c}18(48.6) \\
16(43.2) \\
0(0.0) \\
3(8.1)\end{array}$ & $\begin{array}{c}21(65.6) \\
11(34.4) \\
0(0.0) \\
0(0.0)\end{array}$ & $\begin{array}{c}48 \\
48 \\
1 \\
3\end{array}$ & 0.02 \\
\hline $\begin{array}{l}\text { Social } \\
\text { bookmarking } \\
\text { sites }\end{array}$ & $\begin{array}{l}\text { Frequent } \\
\text { Infrequent } \\
\text { Unaware } \\
\text { No answer }\end{array}$ & $\begin{array}{c}0(0.0) \\
12(38.7) \\
19(61.3) \\
0(0.0) \\
\end{array}$ & $\begin{array}{c}0(0.0) \\
16(43.2) \\
21(56.8) \\
0(0.0) \\
\end{array}$ & $\begin{array}{c}3(9.4) \\
15(46.9) \\
14(43.8) \\
0(0.0) \\
\end{array}$ & $\begin{array}{c}3 \\
43 \\
54 \\
0 \\
\end{array}$ & 0.18 & $\begin{array}{c}0(0.0) \\
26(83.9) \\
5(16.1) \\
0(0.0) \\
\end{array}$ & $\begin{array}{c}0(0.0) \\
20(54.1) \\
17(45.9) \\
0(0.0) \\
\end{array}$ & $\begin{array}{c}0(0.0) \\
23(71.9) \\
9(28.1) \\
0(0.0) \\
\end{array}$ & $\begin{array}{c}0 \\
69 \\
39 \\
0 \\
\end{array}$ & 0.03 \\
\hline Podcasts & $\begin{array}{l}\text { Frequent } \\
\text { Infrequent } \\
\text { Unaware } \\
\text { No answer }\end{array}$ & $\begin{array}{c}2(6.5) \\
24(77.4) \\
4(12.9) \\
1(3.2)\end{array}$ & $\begin{array}{c}1(2.7) \\
32(86.5) \\
4(10.8) \\
0(0.0)\end{array}$ & $\begin{array}{c}6(18.8) \\
24(75.0) \\
2(6.3) \\
0(0.0) \\
\end{array}$ & $\begin{array}{c}9 \\
80 \\
10 \\
1 \\
\end{array}$ & 0.21 & $\begin{array}{c}0(0.0) \\
29(93.5) \\
2(6.5) \\
0(0.0)\end{array}$ & $\begin{array}{c}0(0.0) \\
34(91.9) \\
3(8.1) \\
0(0.0)\end{array}$ & $\begin{array}{c}0(0.0) \\
30(93.8) \\
2(6.3) \\
0(0.0)\end{array}$ & $\begin{array}{c}0 \\
93 \\
7 \\
0\end{array}$ & 1.00 \\
\hline $\begin{array}{l}\text { Video upload/ } \\
\text { sharing }\end{array}$ & $\begin{array}{l}\text { Frequent } \\
\text { Infrequent } \\
\text { Unaware } \\
\text { No answer }\end{array}$ & $\begin{array}{c}15(48.4) \\
15(48.4) \\
0(0.0) \\
1(3.2)\end{array}$ & $\begin{array}{c}14(37.8) \\
22(59.5) \\
0(0.0) \\
1(2.7)\end{array}$ & $\begin{array}{c}22(68.8) \\
9(28.1) \\
0(0.0) \\
1(3.1) \\
\end{array}$ & $\begin{array}{c}51 \\
46 \\
0 \\
3 \\
\end{array}$ & 0.03 & $\begin{array}{c}4(12.9) \\
27(87.1) \\
0(0.0) \\
0(0.0) \\
\end{array}$ & $\begin{array}{c}1(2.7) \\
34(91.9) \\
1(2.7) \\
1(2.7) \\
\end{array}$ & $\begin{array}{c}4(12.5) \\
28(87.5) \\
0(0.0) \\
0(0.0)\end{array}$ & $\begin{array}{c}9 \\
89 \\
1 \\
1 \\
\end{array}$ & 0.25 \\
\hline Skype & $\begin{array}{l}\text { Frequent } \\
\text { Infrequent } \\
\text { Unaware } \\
\text { No answer }\end{array}$ & $\begin{array}{c}10(32.3) \\
21(67.7) \\
0(0.0) \\
0(0.0)\end{array}$ & $\begin{array}{c}10(27.0) \\
27(73.0) \\
0(0.0) \\
0(0.0)\end{array}$ & $\begin{array}{c}6(18.8) \\
26(81.3) \\
0(0.0) \\
0(0.0)\end{array}$ & $\begin{array}{c}26 \\
74 \\
0 \\
0\end{array}$ & 0.49 & $\begin{array}{c}3(9.7) \\
28(90.3) \\
0(0.0) \\
0(0.0)\end{array}$ & $\begin{array}{c}1(2.7) \\
35(94.6) \\
1(2.7) \\
0(0.0)\end{array}$ & $\begin{array}{c}0(0.0) \\
32(100) \\
0(0.0) \\
0(0.0)\end{array}$ & $\begin{array}{c}4 \\
95 \\
1 \\
0 \\
\end{array}$ & 0.18 \\
\hline $\begin{array}{l}\text { Text } \\
\text { messaging }\end{array}$ & $\begin{array}{l}\text { Frequent } \\
\text { Infrequent } \\
\text { Unaware } \\
\text { No answer }\end{array}$ & $\begin{array}{c}29(93.5) \\
2(6.5) \\
0(0.0) \\
0(0.0) \\
\end{array}$ & $\begin{array}{c}36(97.3) \\
1(2.7) \\
0(0.0) \\
0(0.0) \\
\end{array}$ & $\begin{array}{c}32(100) \\
0(0.0) \\
0(0.0) \\
0(0.0) \\
\end{array}$ & $\begin{array}{c}97 \\
3 \\
0 \\
0 \\
\end{array}$ & 0.40 & $\begin{array}{c}25(77.4) \\
7(22.6) \\
0(0.0) \\
0(0.0) \\
\end{array}$ & $\begin{array}{c}30(81.1) \\
7(18.9) \\
0(0.0) \\
0(0.0) \\
\end{array}$ & $\begin{array}{c}29(90.6) \\
3(9.4) \\
0(0.0) \\
0(0.0) \\
\end{array}$ & $\begin{array}{c}83 \\
17 \\
0 \\
0 \\
\end{array}$ & 0.41 \\
\hline $\begin{array}{l}\text { Online } \\
\text { forums for } \\
\text { specific } \\
\text { interests }\end{array}$ & $\begin{array}{l}\text { Frequent } \\
\text { Infrequent } \\
\text { Unaware } \\
\text { No answer }\end{array}$ & $\begin{array}{c}4(12.9) \\
24(77.4) \\
1(3.2) \\
2(6.5) \\
\end{array}$ & $\begin{array}{c}8(21.6) \\
25(67.6) \\
3(8.1) \\
1(2.7) \\
\end{array}$ & $\begin{array}{c}6(18.8) \\
24(75.0) \\
1(3.1) \\
1(3.1) \\
\end{array}$ & $\begin{array}{c}18 \\
73 \\
5 \\
4 \\
\end{array}$ & 0.78 & $\begin{array}{c}0(0.0) \\
31(100) \\
0(0.0) \\
0(0.0)\end{array}$ & $\begin{array}{c}0(0.0) \\
36(97.3) \\
1(2.7) \\
0(0.0) \\
\end{array}$ & $\begin{array}{c}2(6.3) \\
29(90.6) \\
1(3.1) \\
0(0.0) \\
\end{array}$ & $\begin{array}{c}2 \\
96 \\
2 \\
0 \\
\end{array}$ & 0.32 \\
\hline $\begin{array}{l}\text { Online file } \\
\text { storage \& } \\
\text { access }\end{array}$ & $\begin{array}{l}\text { Frequent } \\
\text { Infrequent } \\
\text { Unaware } \\
\text { No answer }\end{array}$ & $\begin{array}{c}21(67.7) \\
10(32.3) \\
0(0.0) \\
0(0.0)\end{array}$ & $\begin{array}{c}25(67.6) \\
11(29.7) \\
1(2.7) \\
0(0.0)\end{array}$ & $\begin{array}{c}25(78.1) \\
7(21.9) \\
0(0.0) \\
0(0.0) \\
\end{array}$ & $\begin{array}{c}71 \\
28 \\
1 \\
0 \\
\end{array}$ & 0.69 & $\begin{array}{c}14(45.2) \\
17(54.8) \\
0(0.0) \\
0(0.0)\end{array}$ & $\begin{array}{c}18(48.6) \\
18(48.6) \\
1(2.7) \\
0(0.0) \\
\end{array}$ & $\begin{array}{c}20(62.5) \\
12(37.5) \\
0(0.0) \\
0(0.0)\end{array}$ & $\begin{array}{c}52 \\
47 \\
1 \\
0\end{array}$ & 0.41 \\
\hline Wikis & $\begin{array}{l}\text { Frequent } \\
\text { Infrequent }\end{array}$ & $\begin{array}{c}17(54.8) \\
9(29.0)\end{array}$ & $\begin{array}{l}11 \text { (29.7) } \\
22(59.5)\end{array}$ & $\begin{array}{l}21(65.6) \\
11(34.4)\end{array}$ & $\begin{array}{l}49 \\
42\end{array}$ & 0.02 & $\begin{array}{c}1(3.2) \\
21(67.7)\end{array}$ & $\begin{array}{c}3(8.1) \\
31(83.8)\end{array}$ & $\begin{array}{l}11(34.4) \\
21(65.6)\end{array}$ & $\begin{array}{l}15 \\
73\end{array}$ & $<0.0001$ \\
\hline
\end{tabular}




\begin{tabular}{|c|c|c|c|c|c|c|c|c|c|c|c|}
\hline & $\begin{array}{l}\text { Unaware } \\
\text { No answer }\end{array}$ & $\begin{array}{c}4(12.9) \\
1(3.2)\end{array}$ & $\begin{array}{c}4(10.8) \\
0(0.0)\end{array}$ & $\begin{array}{l}0(0.0) \\
0(0.0)\end{array}$ & $\begin{array}{l}8 \\
1\end{array}$ & & $\begin{array}{c}9(29.0) \\
0(0.0)\end{array}$ & $\begin{array}{l}3(8.1) \\
0(0.0)\end{array}$ & $\begin{array}{l}0(0.0) \\
0(0.0)\end{array}$ & $\begin{array}{l}3 \\
0\end{array}$ & \\
\hline $\begin{array}{l}\text { Online } \\
\text { presentation } \\
\text { banks }\end{array}$ & $\begin{array}{l}\text { Frequent } \\
\text { Infrequent } \\
\text { Unaware } \\
\text { No answer }\end{array}$ & $\begin{array}{c}0(0.0) \\
22(71.0) \\
9(29.0) \\
0(0.0)\end{array}$ & $\begin{array}{c}7(18.9) \\
26(70.3) \\
4(10.8) \\
0(0.0)\end{array}$ & $\begin{array}{c}3(9.4) \\
24(75.0) \\
5(15.6) \\
0(0.0)\end{array}$ & $\begin{array}{c}10 \\
72 \\
18 \\
0\end{array}$ & 0.046 & $\begin{array}{c}1(3.2) \\
26(83.9) \\
4(12.9) \\
0(0.0)\end{array}$ & $\begin{array}{c}4(10.8) \\
32(86.5) \\
1(2.7) \\
0(0.0)\end{array}$ & $\begin{array}{c}1(3.1) \\
28(87.5) \\
3(9.4) \\
0(0.0)\end{array}$ & $\begin{array}{c}6 \\
86 \\
8 \\
0\end{array}$ & 0.37 \\
\hline $\begin{array}{l}\text { Online } \\
\text { question \& } \\
\text { answer sites }\end{array}$ & $\begin{array}{l}\text { Frequent } \\
\text { Infrequent } \\
\text { Unaware } \\
\text { No answer }\end{array}$ & $\begin{array}{c}0(0.0) \\
26(83.9) \\
5(16.1) \\
0(0.0)\end{array}$ & $\begin{array}{c}3(8.1) \\
31(83.8) \\
3(8.1) \\
0(0.0)\end{array}$ & $\begin{array}{c}3(9.4) \\
28(87.5) \\
1(3.1) \\
0(0.0)\end{array}$ & $\begin{array}{c}6 \\
85 \\
9 \\
0\end{array}$ & 0.21 & $\begin{array}{c}1(3.2) \\
29(93.5) \\
1(3.2) \\
0(0.0)\end{array}$ & $\begin{array}{c}0(0.0) \\
36(97.3) \\
1(2.7) \\
0(0.0)\end{array}$ & $\begin{array}{c}2(6.3) \\
29(90.6) \\
1(3.1) \\
0(0.0)\end{array}$ & $\begin{array}{c}3 \\
94 \\
3 \\
0\end{array}$ & 0.73 \\
\hline $\begin{array}{l}\text { Web-based } \\
\text { project }\end{array}$ & $\begin{array}{l}\text { Frequent } \\
\text { Infrequent } \\
\text { Unaware } \\
\text { No answer }\end{array}$ & $\begin{array}{c}0(0.0) \\
14(45.2) \\
17(54.8) \\
0(0.0) \\
\end{array}$ & $\begin{array}{c}0(0.0) \\
20(54.1) \\
17(45.9) \\
0(0.0)\end{array}$ & $\begin{array}{c}0(0.0) \\
23(71.9) \\
9(28.1) \\
0(0.0) \\
\end{array}$ & $\begin{array}{c}0 \\
57 \\
43 \\
0\end{array}$ & 0.09 & $\begin{array}{c}0(0.0) \\
23(74.2) \\
8(25.8) \\
0(0.0)\end{array}$ & $\begin{array}{c}0(0.0) \\
28(75.7) \\
9(24.3) \\
0(0.0)\end{array}$ & $\begin{array}{c}2(6.3) \\
24(75.0) \\
6(18.8) \\
0(0.0)\end{array}$ & $\begin{array}{c}2 \\
75 \\
23 \\
0\end{array}$ & 0.50 \\
\hline
\end{tabular}

Note: Frequent use, infrequent use, and unaware were compared using Fisher's exact test to calculate p values. $P$ values were reported as the probability of the observed array of cell frequencies plus the sum of the probabilities of all other cell frequency arrays that were equal to or smaller than the probability of the observed array. P values $<0.05$ were considered significant. Avg.: average for three cohorts.

\begin{tabular}{|c|c|c|c|c|c|c|}
\hline \multicolumn{7}{|c|}{$\begin{array}{l}\text { Supplementary Table S. Percentages of frequent and infrequent users of specific social media services in the past } 6 \\
\text { months }\end{array}$} \\
\hline & & \multicolumn{3}{|c|}{ Use (\%) } & \multirow{3}{*}{$\begin{array}{c}\text { Avg. (\%) } \\
(\mathrm{n}=100)\end{array}$} & \multirow[b]{3}{*}{$\mathbf{p}$} \\
\hline & \multirow[b]{2}{*}{ Frequency } & & & & & \\
\hline $\begin{array}{l}\text { Specific social media } \\
\text { service }\end{array}$ & & $\begin{array}{c}2012 \\
(\mathrm{n}=31)\end{array}$ & $\begin{array}{c}2014 \\
(\mathrm{n}=37)\end{array}$ & $\begin{array}{c}2016 \\
(n=32)\end{array}$ & & \\
\hline Facebook & $\begin{array}{l}\text { Frequent } \\
\text { Infrequent } \\
\text { Unaware } \\
\text { No answer }\end{array}$ & $\begin{array}{c}23(74.2) \\
8(25.8) \\
0(0.0) \\
0(0.0)\end{array}$ & $\begin{array}{c}25(67.6) \\
12(32.4) \\
0(0.0) \\
0(0.0)\end{array}$ & $\begin{array}{c}25(78.1) \\
7(21.9) \\
0(0.0) \\
0(0.0)\end{array}$ & $\begin{array}{c}73 \\
27 \\
0 \\
0\end{array}$ & 0.61 \\
\hline Twitter & $\begin{array}{l}\text { Frequent } \\
\text { Infrequent } \\
\text { Unaware } \\
\text { No answer }\end{array}$ & $\begin{array}{c}2(6.5) \\
29(93.5) \\
0(0.0) \\
0(0.0)\end{array}$ & $\begin{array}{c}7(18.9) \\
30(81.1) \\
0(0.0) \\
0(0.0)\end{array}$ & $\begin{array}{c}6(18.8) \\
26(81.3) \\
0(0.0) \\
0(0.0)\end{array}$ & $\begin{array}{c}15 \\
85 \\
0 \\
0 \\
\end{array}$ & 0.28 \\
\hline LinkedIn & $\begin{array}{l}\text { Frequent } \\
\text { Infrequent } \\
\text { Unaware } \\
\text { No answer }\end{array}$ & $\begin{array}{c}0(0.0) \\
30(96.8) \\
1(3.2) \\
0(0.0)\end{array}$ & $\begin{array}{c}1(2.7) \\
36(97.3) \\
0(0.0) \\
0(0.0)\end{array}$ & $\begin{array}{c}1(3.1) \\
31(96.9) \\
0(0.0) \\
0(0.0)\end{array}$ & $\begin{array}{c}2 \\
97 \\
1 \\
0\end{array}$ & 0.83 \\
\hline Google+ & $\begin{array}{l}\text { Frequent } \\
\text { Infrequent } \\
\text { Unaware } \\
\text { No answer }\end{array}$ & $\begin{array}{c}4(12.9) \\
27(87.1) \\
0(0.0) \\
0(0.0)\end{array}$ & $\begin{array}{c}13(35.1) \\
24(64.9) \\
0(0.0) \\
0(0.0)\end{array}$ & $\begin{array}{c}10(31.3) \\
22(68.8) \\
0(0.0) \\
0(0.0)\end{array}$ & $\begin{array}{c}27 \\
73 \\
0 \\
0 \\
\end{array}$ & 0.10 \\
\hline YouTube & $\begin{array}{l}\text { Frequent } \\
\text { Infrequent } \\
\text { Unaware } \\
\text { No answer }\end{array}$ & $\begin{array}{c}16(51.6) \\
14(45.2) \\
0(0.0) \\
1(3.2)\end{array}$ & $\begin{array}{c}26(70.3) \\
11(29.7) \\
0(0.0) \\
0(0.0)\end{array}$ & $\begin{array}{c}23(71.9) \\
9(28.1) \\
0(0.0) \\
0(0.0)\end{array}$ & $\begin{array}{c}65 \\
34 \\
0 \\
1\end{array}$ & 0.27 \\
\hline Blogs & $\begin{array}{l}\text { Frequent } \\
\text { Infrequent } \\
\text { Unaware } \\
\text { No answer }\end{array}$ & $\begin{array}{c}2(6.5) \\
28(90.3) \\
0(0.0) \\
1(3.2)\end{array}$ & $\begin{array}{c}2(5.4) \\
35(94.6) \\
0(0.0) \\
0(0.0)\end{array}$ & $\begin{array}{c}4(12.5) \\
28(87.5) \\
0(0.0) \\
0(0.0)\end{array}$ & $\begin{array}{c}8 \\
91 \\
0 \\
1\end{array}$ & 0.65 \\
\hline $\begin{array}{l}\text { Patient advocacy groups' } \\
\text { sites /patient }\end{array}$ & $\begin{array}{l}\text { Frequent } \\
\text { Infrequent }\end{array}$ & $\begin{array}{c}0(0.0) \\
30(96.8)\end{array}$ & $\begin{array}{c}0(0.0) \\
36(97.3)\end{array}$ & $\begin{array}{c}0(0.0) \\
32(100)\end{array}$ & $\begin{array}{c}0 \\
98\end{array}$ & 0.76 \\
\hline
\end{tabular}




\begin{tabular}{|l|l|c|c|c|c|c|}
\hline communities & Unaware & $1(3.2)$ & $1(2.7)$ & $0(0.0)$ & 2 \\
& No answer & $0(0.0)$ & $0(0.0)$ & $0(0.0)$ & 0 & \\
\hline Online physician & Frequent & $2(6.5)$ & $1(2.7)$ & $0(0.0)$ & 3 & 95 \\
communities & Infrequent & $28(90.3)$ & $35(94.6)$ & $32(100)$ & 0.56 \\
& Unaware & $1(3.2)$ & $1(2.7)$ & $0(0.0)$ & 2 & 0 \\
& No answer & $0(0.0)$ & $0(0.0)$ & $0(0.0)$ & \\
\hline
\end{tabular}

Note: Frequent use, infrequent use, and unaware were compared using Fisher's exact test to calculate $\mathrm{p}$ values. $\mathrm{P}$ values were reported as the probability of the observed array of cell frequencies plus the sum of the probabilities of all other cell frequency arrays that were equal to or smaller than the probability of the observed array. P values $<0.05$ were considered significant. Avg.: average for total study period.

\begin{tabular}{|c|c|c|c|c|c|c|}
\hline \multicolumn{7}{|c|}{$\begin{array}{l}\text { Supplementary Table 3. Responses to “What are your thoughts regarding the following modes of } \\
\text { physician interaction with patients online?” }\end{array}$} \\
\hline & & \multicolumn{3}{|c|}{ Count (\%) } & & \multirow[b]{2}{*}{$\mathbf{P}$} \\
\hline Response & Attitude & $\begin{array}{c}2012 \\
(n=31)\end{array}$ & $\begin{array}{c}2014 \\
(n=37)\end{array}$ & $\begin{array}{c}2016 \\
(n=32)\end{array}$ & $\begin{array}{l}\text { Avg. (\%) } \\
(n=100)\end{array}$ & \\
\hline $\begin{array}{l}\text { Anonymous perusal } \\
\text { of patient communities for } \\
\text { understanding their opinions } \\
\text { and needs }\end{array}$ & $\begin{array}{c}\text { Support } \\
\text { Indifferent } \\
\text { Against } \\
\text { No answer }\end{array}$ & $\begin{array}{c}10(32.3) \\
16(51.6) \\
4(12.9) \\
1(3.2)\end{array}$ & $\begin{array}{c}7(18.9) \\
22(59.5) \\
8(21.6) \\
0(0.0)\end{array}$ & $\begin{array}{l}6(18.8) \\
20(62.5) \\
6(18.8) \\
0(0.0)\end{array}$ & $\begin{array}{c}23 \\
58 \\
18 \\
1\end{array}$ & 0.64 \\
\hline $\begin{array}{l}\text { Anonymous posting on } \\
\text { patient communities to } \\
\text { critique content or advise } \\
\text { patients }\end{array}$ & $\begin{array}{l}\text { Support } \\
\text { Indifferent } \\
\text { Against } \\
\text { No answer }\end{array}$ & $\begin{array}{c}5(16.1) \\
16(51.6) \\
9(29.0) \\
1(3.2)\end{array}$ & $\begin{array}{c}3(8.1) \\
12(32.4) \\
22(59.5) \\
0(0.0)\end{array}$ & $\begin{array}{c}2(6.3) \\
11(34.4) \\
19(59.4) \\
0(0.0)\end{array}$ & $\begin{array}{c}10 \\
39 \\
50 \\
1\end{array}$ & 0.10 \\
\hline $\begin{array}{l}\text { Identified personally, } \\
\text { posting on patient } \\
\text { communities }\end{array}$ & $\begin{array}{l}\text { Support } \\
\text { Indifferent } \\
\text { Against } \\
\text { No answer }\end{array}$ & $\begin{array}{c}5(16.1) \\
11(35.5) \\
14(45.2) \\
1(3.2)\end{array}$ & $\begin{array}{c}1(2.7) \\
8(21.6) \\
28(75.7) \\
0(0.0)\end{array}$ & $\begin{array}{c}1(3.1) \\
13(40.6) \\
18(56.3) \\
0(0.0)\end{array}$ & $\begin{array}{c}7 \\
32 \\
60 \\
1\end{array}$ & 0.046 \\
\hline $\begin{array}{l}\text { Email communication with } \\
\text { patients with results }\end{array}$ & $\begin{array}{c}\text { Support } \\
\text { Indifferent } \\
\text { Against } \\
\text { No answer }\end{array}$ & $\begin{array}{c}4(12.9) \\
8(25.8) \\
18(58.1) \\
1(3.2)\end{array}$ & $\begin{array}{c}8(21.6) \\
11(29.7) \\
18(48.6) \\
0(0.0)\end{array}$ & $\begin{array}{c}7(21.9) \\
7(21.9) \\
17(53.1) \\
1(3.1)\end{array}$ & $\begin{array}{c}19 \\
26 \\
53 \\
2\end{array}$ & 0.83 \\
\hline $\begin{array}{l}\text { Email communication with } \\
\text { patients with medical } \\
\text { queries }\end{array}$ & $\begin{array}{c}\text { Support } \\
\text { Indifferent } \\
\text { Against } \\
\text { No answer }\end{array}$ & $\begin{array}{c}6(19.4) \\
12(38.7) \\
12(38.7) \\
1(3.2)\end{array}$ & $\begin{array}{c}6(16.2) \\
10(27.0) \\
20(54.1) \\
1(2.7)\end{array}$ & $\begin{array}{c}9(28.1) \\
6(18.8) \\
17(53.1) \\
0(0.0)\end{array}$ & $\begin{array}{c}21 \\
28 \\
49 \\
2\end{array}$ & 0.37 \\
\hline $\begin{array}{l}\text { "Friending" of patients on } \\
\text { Facebook }\end{array}$ & $\begin{array}{c}\text { Support } \\
\text { Indifferent } \\
\text { Against } \\
\text { No answer }\end{array}$ & $\begin{array}{c}0(0.0) \\
0(0.0) \\
30(96.8) \\
1(3.2)\end{array}$ & $\begin{array}{c}0(0.0) \\
1(2.7) \\
36(97.3) \\
0(0.0)\end{array}$ & $\begin{array}{c}0(0.0) \\
2(6.3) \\
30(93.8) \\
0(0.0)\end{array}$ & $\begin{array}{c}0 \\
3 \\
96 \\
1\end{array}$ & 0.51 \\
\hline $\begin{array}{l}\text { "Friending" of patients on } \\
\text { Facebook on practice- } \\
\text { dedicated page }\end{array}$ & $\begin{array}{c}\text { Support } \\
\text { Indifferent } \\
\text { Against } \\
\text { No answer }\end{array}$ & $\begin{array}{c}1(3.2) \\
5(16.1) \\
23(74.2) \\
2(6.5)\end{array}$ & $\begin{array}{c}0(0.0) \\
8(21.6) \\
29(78.4) \\
0(0.0)\end{array}$ & $\begin{array}{c}1(3.1) \\
5(15.6) \\
26(81.3) \\
0(0.0)\end{array}$ & $\begin{array}{c}2 \\
18 \\
78 \\
2\end{array}$ & 0.81 \\
\hline $\begin{array}{l}\text { Following a patient's } \\
\text { Twitter account }\end{array}$ & $\begin{array}{c}\text { Support } \\
\text { Indifferent } \\
\text { Against }\end{array}$ & $\begin{array}{c}0(0.0) \\
3(9.7) \\
27(87.1)\end{array}$ & $\begin{array}{c}0(0.0) \\
3(8.1) \\
34(91.9)\end{array}$ & $\begin{array}{c}0(0.0) \\
3(9.4) \\
29(90.6)\end{array}$ & $\begin{array}{c}0 \\
9 \\
90\end{array}$ & 1.00 \\
\hline
\end{tabular}




\begin{tabular}{|l|c|c|c|c|c|c|}
\hline & No answer & $1(3.2)$ & $0(0.0)$ & $0(0.0)$ & 1 & \\
\hline Patient following a & Support & $1(3.2)$ & $3(8.1)$ & $2(6.3)$ & 6 & 0.60 \\
physician's Twitter account & Indifferent & $6(19.4)$ & $8(21.6)$ & $11(34.4)$ & 25 & \\
& Against & $23(74.2)$ & $26(70.3)$ & $19(59.4)$ & 68 & \\
& No answer & 1 & $0(0.0)$ & $0(0.0)$ & 1 & \\
\hline
\end{tabular}

Note: Support, indifferent, and negative attitudes were compared using Fisher’s exact test to calculate p values. P values were reported as the probability of the observed array of cell frequencies plus the sum of the probabilities of all other cell frequency arrays that were equal to or smaller than the probability of the observed array. $\mathrm{P}$ values $<0.05$ were considered significant. Avg.: average for total study period

\begin{tabular}{|c|c|c|c|c|c|c|}
\hline \multicolumn{7}{|c|}{$\begin{array}{l}\text { Supplementary Table } 4 \text {. Responses to questions surrounding the guidelines and legislations regarding physician online } \\
\text { practices and privacy issues }\end{array}$} \\
\hline & & \multicolumn{3}{|c|}{ Count (\%) } & \multirow[b]{2}{*}{$\begin{array}{l}\text { Avg. (\%) } \\
(n=100)\end{array}$} & \multirow[b]{2}{*}{$\mathbf{p}$} \\
\hline Question & Response & $\begin{array}{c}2012 \\
(n=31)\end{array}$ & $\begin{array}{c}2014 \\
(n=37)\end{array}$ & $\begin{array}{c}2016 \\
(n=32)\end{array}$ & & \\
\hline $\begin{array}{l}\text { Are you aware of the CMA's } \\
\text { Physician Guidelines for Online } \\
\text { Communication with Patients? }\end{array}$ & $\begin{array}{c}\text { Unaware } \\
\text { Aware but have not read } \\
\text { Aware and have read } \\
\text { No answer }\end{array}$ & $\begin{array}{l}22(71.0) \\
7(22.6) \\
0(0.0) \\
2(6.5)\end{array}$ & $\begin{array}{c}25(67.6) \\
11(29.7) \\
1(2.7) \\
0(0.0)\end{array}$ & $\begin{array}{c}16(50.0) \\
15(46.9) \\
1(3.1) \\
0(0.0)\end{array}$ & $\begin{array}{c}63 \\
33 \\
2 \\
2\end{array}$ & 0.19 \\
\hline $\begin{array}{l}\text { Are you aware of policies by } \\
\text { other medical representative or } \\
\text { governing bodies concerning } \\
\text { Professionalism and social } \\
\text { media use by physicians? }\end{array}$ & $\begin{array}{c}\text { Unaware } \\
\text { Aware but have not read } \\
\text { Aware and have read } \\
\text { No answer }\end{array}$ & $\begin{array}{l}25(80.6) \\
4(12.9) \\
1(3.2) \\
1(3.2)\end{array}$ & $\begin{array}{l}24(64.9) \\
11(29.7) \\
2(5.4) \\
0(0.0)\end{array}$ & $\begin{array}{l}15(46.9) \\
16(50) \\
1(3.1) \\
0(0.0)\end{array}$ & $\begin{array}{c}64 \\
31 \\
4 \\
1\end{array}$ & 0.02 \\
\hline $\begin{array}{l}\text { Are you aware of the CMPA's } \\
\text { position regarding online } \\
\text { communication with patients? }\end{array}$ & $\begin{array}{c}\text { Unaware } \\
\text { Aware but have not read } \\
\text { Aware and have read } \\
\text { No answer }\end{array}$ & $\begin{array}{c}25(80.6) \\
4(12.9) \\
1(3.2) \\
1(3.2) \\
\end{array}$ & $\begin{array}{c}24(64.9) \\
11(29.7) \\
2(5.4) \\
0(0.0)\end{array}$ & $\begin{array}{c}16(50) \\
12(37.5) \\
4(12.5) \\
0(0.0)\end{array}$ & $\begin{array}{c}65 \\
27 \\
7 \\
1\end{array}$ & 0.08 \\
\hline $\begin{array}{l}\text { Are you aware of your } \\
\text { institution's (if applicable) } \\
\text { policies on the use of online } \\
\text { services and communication in } \\
\text { a professional capacity? }\end{array}$ & $\begin{array}{c}\text { Unaware } \\
\text { Aware but have not read } \\
\text { Aware and have read } \\
\text { No answer }\end{array}$ & $\begin{array}{l}24(77.4) \\
4(12.9) \\
2(6.5) \\
1(3.2)\end{array}$ & $\begin{array}{l}21(56.8) \\
14(37.8) \\
2(5.4) \\
0(0.0)\end{array}$ & $\begin{array}{l}11(34.4) \\
17(53.1) \\
4(12.5) \\
0(0.0)\end{array}$ & $\begin{array}{c}56 \\
35 \\
8 \\
1\end{array}$ & 0.004 \\
\hline $\begin{array}{l}\text { Are you aware of your } \\
\text { province's privacy and health } \\
\text { information protection laws? }\end{array}$ & $\begin{array}{c}\text { Unaware } \\
\text { Aware but have not read } \\
\text { Aware and have read } \\
\text { No answer }\end{array}$ & $\begin{array}{c}19(61.3) \\
10(32.3) \\
1(3.2) \\
1(3.2) \\
\end{array}$ & $\begin{array}{c}23(62.2) \\
12(32.4) \\
2(5.4) \\
0(0.0) \\
\end{array}$ & $\begin{array}{c}16(50) \\
13(40.6) \\
3(9.4) \\
0(0.0)\end{array}$ & $\begin{array}{c}58 \\
35 \\
6 \\
1 \\
\end{array}$ & 0.77 \\
\hline
\end{tabular}

Note: Aware and unaware responses were compared using Fisher's exact test to calculate p values. P values were reported as the probability of the observed array of cell frequencies plus the sum of the probabilities of all other cell frequency arrays that were equal to or smaller than the probability of the observed array. $\mathrm{P}$ values $<0.05$ were considered significant. Avg.: average. 